\title{
Buku dan Penyebaran Ideologi Radikal di Lembaga Pendidikan
}

\author{
Abu Rokhmad \\ Universitas Islam Negeri Walisongo \\ Email:aburokhmad@walisongo.ac.id
}

\begin{abstract}
ABSTRAK
This article aims to examine the use of religious reading books as a medium for the dissemination of radical ideologies in educational institutions. The role of the book as a window of knowledge is undoubted, but the book as a disseminator of radicalism also gets justification. Hardline Islamic groups have used certain reading books as justifiers and reinforcement of the radical notions believed. The contents of the book are then taught and indoctrinated to students and students by teachers through a single interpretation and normative-scriptural approach.
\end{abstract}

Keywords: Literacy Culture, Textbooks, Radical Ideology, Educational Institutions.

\begin{abstract}
ABSTRAK
Artikel ini bertujuan untuk menguji penggunaan buku bacaan keagamaan sebagai media penyebaran ideologi radikal pada lembaga pendidikan. Peran buku sebagai jendela ilmu pengetahuan tidak diragukan, tetapi buku sebagai penyebar paham radikal juga mendapatkan pembenaran. Kelompok Islam garis keras telah menggunakan buku bacaan tertentu sebagai pembenar dan penguat paham radikal yang diyakini. Isi buku tersebut kemudian diajarkan dan diindoktrinasikan kepada pelajar dan mahasiswa oleh para guru melalui penafsiran tunggal dan pendekatan normatif-skriptural.
\end{abstract}

Kata Kunci: Budaya Literasi, Buku Ajar, Ideologi Radikal, Lembaga Pendidikan. 


\section{Pendahuluan}

Buku telah lama disepakati dan ditahbiskan sebagai penanda peradaban tinggi umat manusia. Ia merupakan simbol dan representasi dari budaya baca-tulis (literacy) (lihat Romdhoni 2013, 1). ${ }^{1}$ Seluruh peradaban, termasuk peradaban Islam sangat tergantung pada tradisi ini baik dalam proses pertumbuhan maupun pelestariannya (Pedersen 1996). Bermula dari tradisi baca-tulis ini, bangsa-bangsa di dunia meraih kejayaan peradaban tinggi.

Literasi merupakan tradisi orang dan bangsa yang hebat. Orang-orang cerdas identik dengan buku, baik sebagai pembaca maupun penulis buku. Pramoedya Ananta Toer mengatakan, "orang boleh pandai setinggi langit, tapi selama ia tidak menulis, ia akan hilang di dalam masyarakat dan dari sejarah. Menulis adalah bekerja untuk keabadian" (Toer 2005). Negara yang unggul ilmu pengetahuan dan teknologi (IPTEK) serta peradabannya pasti negara yang peduli dengan dunia buku dan rakyatnya gemar membaca buku. Makin banyak buku yang ditulis, diterbitkan dan dibaca, makin kentara kemajuan suatu bangsa. Buku ibarat jalan dan obor sekaligus bagi kemajuan peradaban manusia.

Manusia memiliki banyak alat atau instrumen (misalnya, telpon untuk mendengar dan komunikasi jarak jauh, mikroskop untuk melihat bendabenda kecil) untuk menjalani hidupnya. Di antara sekian banyak instrumen itu, kata penulis Argentina, Jorge Luis Borges, yang paling penting adalah buku. Buku merupakan kepanjangan dari ingatan dan imajinasi (Laksono 2016, 7). Tanpa bantuan buku, daya jangkau ingatan sangat terbatas. ${ }^{2}$ Buku sanggup menampung catatan hingga ratusan bahkan ribuan tahun.

\footnotetext{
${ }^{1}$ Secara bahasa, literasi (literacy) artinya baca-tulis, melek aksara atau keberaksaraan. Literasi juga diartikan sebagai the ability to read and writing atau ma'rifat al-qira'at wa alkitabat. Secara sederhana, literasi merupakan tradisi membaca-menulis sebagai aktivitas intelektual yang dapat mengangkat martabat bangsa. Tujuan akhir dari literasi adalah lahirnya peradaban ilmu pengetahuan.

2 Bagi bangsa dengan tradisi hafalan yang kuat (qawiy al-dzakirah) sekalipun, seperti bangsa Arab, perjalanan sejarahnya juga menuju pada tradisi baca-tulis. Hal ini bisa dilihat dari kekhawatiran shahabat Umar ibn Khattab akan hilangnya al-Qur'an bersamaan dengan meninggalnya para huffadz al-Qur'an pada saat perang Yamamah (11 H). Lalu Umar usul kepada Abu Bakar untuk menuliskan dan membukukan al-Qur'an dalam satu mushaf (baca Qaththan 1988).
} 
Dengan buku, imajinasi sekompleks apapun dapat diabadikan sehingga tidak mudah hilang.

Lazim dikemukakan bahwa buku adalah jendela dunia dan sumber ilmu pengetahuan. Fakta itu tak terbantahkan karena dibuktikan oleh banyak orang. Buku membantu kita menjelajahi dunia, meski tubuh kita ada di dalam kamar. Seluruh ilmu pengetahuan yang pernah ditemukan di bumi ini tersimpan dalam buku. Hal ini sangat memudahkan generasi mendatang untuk mempelajari suatu ilmu, dari yang paling dasar hingga yang paling sulit.

Karena itulah, buku menjadi idola dalam dunia pendidikan. Ia dipuja karena peran dan posisinya yang sangat penting dalam proses belajar-mengajar. Hebatnya lagi, buku dapat bertugas bergantian dengan guru. Jika guru tidak hadir, buku mampu menjalankan tugasnya dengan baik di kelas dan bahkan di rumah. Tetapi guru meski bisa menggantikan posisi buku, tetapi tetap tak bisa tampil sempurna seperti buku. Nilai ekonomi buku juga sangat besar dalam pendidikan sehingga diperebutkan oleh banyak pihak. Buku telah menjadi industri dan ladang mencari keuntungan.

Dari sisi lain, buku sering dicurigai dan menjadi obyek vandalisme. Sebuah buku sering dianggap memuat ajaran sesat yang dapat membahayakan keyakinan (aqidah) mayoritas. Buku juga sering dianggap mengajarkan ideologi tertentu yang dapat membahayakan keamanan negara. Akhirnya, buku tersebut dicari-cari, bukan untuk dibaca dan dikaji secara kritis tapi untuk dibakar (bibliokasm atau librisida: tindakan memusnahkan buku) dan dinistakan. Sejarah pembakaran buku sudah berlangsung sangat panjang. Pelakunya bermacam-macam, oknum negara, agamawan, orang awam bahkan para intelek (Baez 2013).

Pada masa kuno, sejarah penghancuran buku pertama ditemukan di daerah Sumeria, tempat pertama kali kertas ditemukan. Berdasarkan temua arkeologis di tahun 1924 ada 100.000 buku yang saat itu masih dalam bentuk tablet (lempengan yang dibuat dari tanah liat) telah hancur akibat perang yang terus berkecamuk di wilayah itu. Penghancuran buku juga terjadi di Mesir, Yunani, Israel, Cina, Romawi, beserta kisah berdiri dan runtuhnya perpustakaan Alexandria dan perpustakaan kuno lainnya. Bahkan, yang mengejutkan, filsuf terkenal Plato juga pernah membakar 
buku/ risalah-risalah Demokritos yang tak diinginkan Plato. Menurut Laersius, Plato semasa mudanya, seusai kontes di Teater Dionisisu, menemui Sokrates dan membakar puisi-puisinya (Baez 2013, 47).

Otoritas gereja pernah membakar buku di depan umum, terutama buku-buku yang dianggap sesat/ bidah. Tidak hanya buku, bahkan penulisnyapun kerap dibakar bersama-sama dengan buku yang ditulis. Gereja melakukan inkuisisi, sebagai lembaga hukum keagamaan paling berkuasa yang pernah didirikian untuk menumpas perbedaan pemikiran di seluruh Eropa. Di masa ini sensor, penangkapan, penyiksaan,dan penghancuran terhadap buku yang dianggap bidah terjadi secara merajalela. Pada 1559, saat gereja Katolik dipimpin Paus IV disusunlah daftar buku yang paling membahayakan iman yang diberi judul Index Librorum Prohibitorum (Indeks Buku-buku Terlarang). Buku ini memuat 550 penulis dan karyanya yang dilarang dibaca, sekaligus memudahkan inkuisitor dalam menjalankan tugas (Baez 2013, 161).

Kasus pembakaran buku terus terjadi, baik di Barat dan Timur, termasuk yang terjadi di Irak tahun 2003 hingga di Indonesia. Irak adalah tempat buku pertama ditemukan, tetapi telah kehilangan hampir satu juta buku yang hilang atau lenyap. Baez menyatakan, "Irak adalah sebuah bangsa yang telah kehilangan sebagian besar ingatannya. Buku-bukunya kini menjadi abu, karya-karya budayanya dijual di pasar. Irak adalah korban pertama pemusnahan kebudayaan pada abad ke-21" (Baez 2013, 303).

Indonesia juga memiliki sejarah panjang pemusnahan buku. Salah satunya terjadi pada 2007, ketika pihak berwenang di Jawa Barat, Jawa Tengah dan Sulawesi, membakar lebih dari 30.000 buku ajar SMA di hadapan para siswa. Isi buku tersebut dipandang tidak sejalan dengan sejarah versi pemerintah menyangkut peristiwa 1965 (Baez 2013, 242-43).

Tentu saja, aksi bibliokasm dapat dilakukan dengan bermacam cara, mulai dari pembakaran hingga pelarangan peredaran buku. Di atasnya, masih ada perilaku yang lebih sadis dari sekedar pembakaran buku,yaitu tidak mau membaca buku. Belakangan, buku juga disinyalir menjadi penyebar paham radikal di kalangan pelajar dan mahasiswa di lembaga pendidikan (Balitbang Semarang 2017; Rokhmad 2011). 
Tumbangnya pemerintahan Soeharto membuat kelompok-kelompok radikal yang dulu tiarap menjadi bangun kembali. Euforia reformasi ternyata juga berimbas dengan masuknya buku-buku berideologi radikal seperti jihad dari Timur Tengah ke Indonesia. Para penerbit pun tidak segan-segan untuk menerbitkan buku-buku terjemahan tersebut kepada masayarakat. International Cricis Group (ICG) melalui laporan rutinnya mensinyalir bahwa buku-buku jihad diterbitkan oleh semacam jaringan penerbit yang memiliki kedekatan ideologis dengan Jamaah Islamiyah (JI). Sebagian besar perusahaan penerbitan yang terkait JI berada di Solo, dikelola oleh alumni Pondok Pesantren al-Mukmin, yang didirikan oleh Ba'asyir dan Sungkar, di Ngruki, Solo. Meskipun hanya sedikit sekali yang kelihatannya menjadi anggota IKAPI, hampir seluruhnya merupakan anggota Serikat Penerbit Islam atau SPI, sebuah asosiasi yang tampaknya didominasi oleh Ngruki. Beberapa penerbit tersebut adalah Al-Alaq, kelompok Arafah, Kelompok al-Qowam, Kelompok Aqwam, Kafayeh Cipta Media (KCM), Penerbit di daerah Solo yang lain, dan Ar-Rahmah media.

Penelitian Lembaga Kajian Islam dan Perdamaian Jakarta pada tahun 2010 menunjukkan sebanyak 48,9\% siswa di Jabodetabek menyatakan persetujuannya terhadap aksi kekerasan. Hasil survey di atas sekaligus bisa menyadarkan para guru, khususnya guru Pendidikan Agama Islam (PAI), bahwa ada bahaya yang sedang mengancam para siswanya. Persetujuan atau penerimaan terhadap suatu nilai adalah tahap awal dari 5 tahapan ranah sikap atau afektif seseorang dalam pandangan David R. Krathwohl yaitu: (1) penerimaan (receiving), (2) penanggapan (responding), (3) menilai (valuing), (4) mengorganisasikan (organization), dan (5) karakterisasi dengan nilai atau kompleks nilai (characterization by a value or value complex) (Krathwohl 1964, 55). Ini berarti, jika persetujuan siswa terhadap tindakan radikal itu dibiarkan, bisa jadi akan mengakibatkan mereka memiliki kepribadian yang suka berbuat kekerasan sebagai cara yang ditempuh untuk mencapai tujuan. Radikalisme-setidaknya pada tataran pemikiran—telah memeroleh dukungan dari masyarakat sekolah.

Pada tingkat perguruan tinggi, kecenderungan mahasiswa untuk mendukung tindakan radikalisme juga sangat tinggi. Hal ini terungkap 
dalam penelitian Ditjen Dikti tentang Islam Kampus yang melibatkan 2466 sampel mahasiswa dari berbagai perguruan tinggi ternama di Indonesia. Ketika para mahasiswa ditanya tentang pelaksanaan amar makruf nahi munkar dalam bentuk sweeping tempattempat yang dianggap sumber maksiyat, mereka menjawab sebagai berikut: sekitar 65\% (1594 responden) mendukung dilaksanakannya sweeping kemaksiyatan, 18\% (446 responden) mendukung sekaligus berpartisipasi aktif dalam kegiatan sweeping. Sekitar 11\% (268 responden) menyatakan tidak mendukung sweeping, dan sisanya, 6\% (158 responden) tidak memberikan jawabannya. Selanjutnya, mereka yang mendukung sweeping beralasan bahwa kegiatan sweeping tersebut sebagai bagian dari perintah agama (88\%), mendukung sweeping karena berpendapat bahwa aparat keamanan tidak mampu menegakkan hukum (4\%), dan karena alasan dekadensi moral (8\%) (Fadjar 2007, 35).

Riset di atas menunjukkan bahwa buku berpengaruh besar dalam penyebaran paham radikal, khususnya pada kelompok Kerohanian Islam (Rohis) di SMU dan Perguruan Tinggi Umum. Mereka memiliki buku bacaan khusus sebagai sumber doktrin dan ideologi gerakan Islam yang diikutinya.

Setiap buku memiliki dan mengusung ideologi penulisnya. Ada keyakinan dan cita-cita besar yang hendak disampaikan kepada pembaca dengan harapan besar supaya pembaca terpengaruh dan mengikuti keyakinan tersebut. Di hadapan pembaca yang belum dewasa dan terbatas wawasannya, isi buku akan mengeras menjadi sebentuk keyakinan kaku dan tak mudah didialogkan Di tangan dosen yang berwawasan sempit dan berafiliasi dengan politik tertentu, buku itu akan menjadi 'seperti' firman Tuhan atau sabda nabi yang tak boleh dibantah.

\section{Buku dan Ideologinya}

Secara bahasa, ideologi semakna dengan ajaran, aliran, fikrah, filsafat, haluan, paham, pandangan, dan pemikiran (Endarmoko 2006, 242). Ideology (bahasa Yunani, idea berarti gagasan, dan logos berarti kajian atau ilmu tentang) adalah kajian tentang ide-ide yang menyangkut filsafat, agama, ekonomi, politik dan lain-lain (Rosda 1995, 152). 
Awalnya, istilah ideologi dikenalkan Antoine Destutt de Tracy (1754-1836) pada 1796. Tracy mulanya memandang ideologi sebagai ilmu tentang pikiran manusia yang mampu menunjukkan arah yang benar menuju masa depan. Dengan jalan pencerahan yang sejati, Tracy ingin meneruskan kemajuan dengan memperbaiki manusia-untuk menunjukkan ide-ide mana yang salah dan mengembangkan sistem pendidikan yang sekuler (Eatwell and Wright 2001, 5).

Namun pengkaitan ideologi dengan ilmu dan kajian yang obyektif ini, ternyata tidak bertahan lama. Ideologi segera menjadi istilah negatif yang mengacu pada obyek dan bukan pada bentuk kajian ilmiah. Napoleon Bonaparte (1769-1821) adalah tokoh pertama yang menggunakan istilah ideologi dengan cara negatif. Napoleon mulai mempertautkan ideologi dengan karakter seperti keinginan a priori untuk mengubah cara lama dan 'memperbaiki' kehidupan masyarakat, dan/ atau mendukung kepercayaan yang cocok dengan kepentingan mereka (Eatwell and Wright 2001, 6).

Karl Marx (1818-1883) malah melihat konsep ideologi pada ranah teori politik dan sosial. Marx memandang bahwa ideologi bukan sekedar "isme-isme" melainkan terefleksi dalam semua sisi masyarakat yang menopang kelas penguasa. Menurut Marx, ideologi adalah prinsip "legal, politis, religius, estetis, atau filosofis" yang memperkuat masyarakat kapitalis. Berbeda dengan Tracy, Marx melihat kemajuan suatu bangsa tergantung dari kekuatan ekonominya bukan karena pemimpin atau ide besar (Eatwell and Wright 2001, 7). Kendati demikian, Marx menyadari bahwa konsep ideologi juga bisa diterapkan pada sistem kepercayaan sekalipun terdapat keragaman dalam penggunannya. Terdapat ketegangan antara makna negatif kata "ideologi" sebagai sesuatu yang menyelubungi kepentingan masyarakat kapitalis, dan makna yang lebih umum di mana ideologi dipandang sebagai bagian yang diperlukan dalam sistem kepercayaan semua masyarakat (Eatwell and Wright 2001, 8).

Seorang komunis asal Italia, Antonio Gramsci (1891-1937) percaya bahwa kekuasaan satu kelas atas kelas yang lain tidak sekedar bersifat ekonomis dengan didukung oleh aparat negara yang koersif. Kekuasaan ini tergantung pada hegemoni, kekuatan budaya dan ideologi. Dalam bentuk paripurnanya, ideologi menjadi semacam akal sehat yang 
tidak mudah dilawan. Untuk melawan kekuatan ideologi, Gramsci menyodorkan peran cendekiawan yang dibaginya menjadi cendekiawan tradisonal dan organik. Cendekiawan tradisonal menganggap diri bebas dari kelas dan rasional: akademisi di universitas dan rohaniawan atau tokoh agama. Para cendekiawan ini bisa menciptakan kontrahegemoni melalui kekuatan tulisan dan peran mereka di masyarakat (Eatwell and Wright 2001).

Ideologi-dengan demikian-setidaknya mencakup empat hal, yaitu ideologi sebagai pemikiran politik; ideologi sebagai kepercayaan dan norma; ideologi sebagai bahasa, simbol, dan mitos; dan ideologi sebagai kekuasaan elit (Eatwell and Wright 2001, 3). Jika keempatnya berkumpul dan menjadikan buku bacaan sebagai medianya, maka lengkaplah buku memiliki ideologinya sendiri.

Dengan kata lain, buku-buku yang dijadikan bacaan keagamaan Islam di kerohanian Islam tertentu, boleh jadi menganut Islamisme (dan bukan Islam), yakni menjadikan Islam sebagai politik keagamaan, yang menggunakan simbol agama untuk tujuan politik. Islam dan Islamisme jelas beda. Islam berkaitan dengan iman dan Islam sebagai agama. Islamisme berhubungan dengan tatanan politik. Kata Tibi, Islamisme bukan sekedar politik, tetapi politik yang diagamaisasikan. Agamaisasi politik berarti promosi suatu tatanan politik yang dipercaya beremanasi dari kehendak Allah Swt dan bukan kedaulatan rakyat. Islamisme mendambakan kebangkitan kembali sejarah dan kejayaan Islam. Model beragama penganut Islamisme cenderung normatif-radikal (Tibi 2016).

Dalam kerangka pikir seperti di atas, kehadiran sebuah buku bacaan-apalagi bacaan keagamaan-sangat penting bagi siswasiswi dan mahasiswa untuk menambah dan memperdalam agama Islam yang diyakininya. Setiap buku yang dibaca, akan mempengaruhi pembacanya. Lebih-lebih bila dilakukan secara intensif, didiskusikan dan diindoktrinasikan oleh guru, dosen atau pemimbingnya.

Secara hermenetik, sebuah buku mengandung pesan dan mewakili kepentingan dari penulisnya. Pesan itu diyakini kebenarannya dan diharapkan pembaca menerima dan mengikuti pesan tersebut. Pesan yang diyakini kebenarannya-apalagi pesan tersebut bersumber dari firman Tuhan dan sabda Nabi-akan ditanamkan lebih bersemangat 
lagi dan diklaim dengan satu makna tunggal. Satu pesan, satu tafsir dan satu pemahaman, sehingga tidak ada lagi makna lain selain dari makna tekstual.

Pada dasarnya, sebuah buku tidak mungkin memuat pesan tunggal. Buku merupakan ruang multidimensi yang sarat tafsir, bercampur aduk satu kutipan dengan kutipan lainnya dan saling berbenturan. Kelahiran pembaca-bersamaan dengan kelahiran buku—kata Roland Barthes, berakibat pada kematian penulis. Yakni terciptanya sebuah ruang kebebasan penafsiran bagi pembaca, ketika ia tidak lagi menggantungkan dirinya pada otoritas penulis dalam memahami buku (Rokhmad 2010, 23).

Tetapi, bagi penganut Islam politik (Islamisme), pendekatan hermeneutik tidak berlaku. Bersesuaian dengan model keagamaan mereka yang normatif-harfiyyah, kehadiran buku sama artinya dengan kehadiran penulis yang membawa pesan suci yang tak mungkin dibantahkan. Para pembacanya juga bertindak seolah-olah sebagai "rasul" utusan penulisnya, yang menyampaikan pesan apa adanya dan tidak boleh menyimpang dari makna harfiyyah buku tersebut.

Disinilah pesan ideologis, yang perlu 'dicurigai' dan 'diantisipasi' aspek-aspek 'destruktif' dari sebuah buku. Implikasinya, para pembaca harus cerdas dalam membaca buku. Namun harus diakui, bahwa para siswa dan mahasiswa belum semuanya dewasa dalam mencerna isi sebuah buku, lebih-lebih buku keagamaan. Dengan kemampuan di bidang ilmu keagamaan yang relatif terbatas, mereka bisa saja salah paham dalam memahami ajaran agama yang ditulis dalam sebuah buku. Disinilah pentingnya guru agama yang membimbing mereka dalam memahami ajaran agama.

\section{Pendidikan Agama dan Paham Radikal}

Tak bisa dipungkiri bahwa agama sangat penting bagi kehidupan manusia. Di tengah keterbatasannya, manusia selalu mencari-cari 'sesuatu di luar dirinya yang berkualitas maha' untuk membantu menyelesaikan persoalannya. Jalan untuk menemukan yang maha itu disediakan oleh agama. 
Sosiolog agama, Elizabeth K. Nottingham berpandangan bahwa secara empiris, agama memiliki fungsi di masyarakat, antara lain sebagai; (1) faktor yang mengintegrasikan masyarakat; (2) faktor yang mendisintegrasikan masyarakat; (3) faktor yang bisa melestarikan nilainilai sosial; dan (4) faktor yang bisa memainkan peran kreatif, inovatif dan bahkan revolusionir (Nottingham 1997, 42).

Dengan bahasa yang berbeda, Thomas F. O'Dea (1996) mengintrodusir enam fungsi agama bagi manusia, yaitu: (1) Sebagai pendukung, pelipur lara, dan perekonsiliasi; (2) Agama menawarkan sarana hubungan transendental melalui rituang penyembhan dan upacara ibadat; (3) Penguat norma-norma dan nilai-nilai yang sudah ada di masyarakat; (4) Pengkoreksi fungsi (nilai-nilai) yang sudah ada; (5) Pemberi identitas diri; dan (6) Agama bersangkut-paut dengan pertumbuhan dan kedewasaan individu.

Satu fungsi lagi (yang luput dari pengamatan sosiolog agama di atas) yang mesti disebut adalah fungsi edukatif. Ajaran agama merupakan sumber nilai yang sangat kaya bagi pendidikan manusia. Sumbernya yang berasal wahyu membuat setiap penganutnya meyakini kebenaran ajarannya. Oleh karena itulah, misi utama agama Islam adalah memberi petunjuk (hudan) kepada manusia untuk kehidupan yang baik. Salah satu proses penting untuk mencapai kehidupan yang lebih baik adalah lewat pendidikan dan pengajaran.

Fungsi-fungsi agama dalam Islam disebut lebih rinci lagi. Sesuai dengan klaim Islam sebagai agama rahmatan lil'alamin, ajaran-ajaran Islam sarat dengan perintah tentang ibadah dan mu'amalah. Ada ahli yang mengklasifikasi inti pokok ajaran Islam berupa aspek ibadah dan aspek tanggung jawab manusia untuk memajukan kebenaran (amar ma'ruf) dan mencegah kerusakan (nahi munkar). Kebahagiaan di dunia dan akhirat menjadi inti diturunkannya risalah Islam. Al-Qur'an dan al-Hadits menjadi petunjuk bagi umat Islam untuk mencapai tujuan di atas.

Konstitusi Indonesia, yaitu UUD Negara Republik Indonesia 1945 menetapkan agama sebagai elemen penting dalam pendidikan. Komitmen ini diwakili oleh kata kunci dalam konstitusi dan berbagai perundang-undangan, seperti Ketuhanan, ketakwaan, keimanan dan 
akhlak mulia. Ketuhanan Yang Maha Esa disebut dalam sila pertama falsafah hidup bangsa, yakni Pancasila. UUD Negara Republik Indonesia memperkuat komitmen keagamaannya dalam Pasal 29.

Watak keberagamaan itu diperkuat lagi dalam UU No. 20 Tahun 2003 tentang Sistem Pendidikan Nasional. Pasal 3 menyebutkan bahwa: "pendidikan nasional berfungsi menumbuhkembangkan dan membentuk watak serta peradaban bangsa yang bermartabat dalam rangka mencerdaskan kehidupan bangsa, bertujuan untuk berkembangnya potensi peserta didik agar menjadi manusia yang beriman dan bertakwa kepada Tuhan Yang Maha Esa, berakhlak mulia, sehat, berilmu, cakap, kreatif, mandiri dan menjadi warga Negara yang demokratis dan bertanggung jawab."

Selain itu, kedudukan pendidikan agama dalam UU Sisdiknas sangat istimewa karena merupakan satu-satunya mata pelajaran yang wajib diajarkan di seluruh jalur, jenjang dan jenis pendidikan (Pasal 37 dan 38). Peraturan Pemerintah No. 55 Tahun 2007 tentang Pendidikan Agama dan Keagamaan makin memperkokoh kedudukan PAI pada semua jenjang pendidikan di Indonesia. Karena itulah, disepakati bahwa agama perlu diajarkan secara formal di sekolah dan maupun di masyarakat.

Pendidikan agama diartikan pendidikan yang materi bahasannya berkaitan dengan keimanan, ketakwaan, akhlak dan ibadah kepada Tuhan. Dengan demikian, pendidikan ini berkaitan dengan pembinaan mental-spiritual yang selanjutnya dapat mendasari tingkah laku manusia dalam berbagai bidang kehidupan. Pendidikan agama tidak terlepas dari upaya menanamkan nilai-nilai serta unsur agama pada jiwa seseorang (Nata 2001, 195). Peningkatan potensi spiritual itu pada akhirnya bertujuan untuk optimalisasi berbagai potensi yang dimiliki manusia yang aktualisasinya mencerminkan harkat dan martabatnya sebagai makhluk Tuhan (Pendis 2007, 2).

Tujuan pendidikan dalam Islam adalah untuk membentuk manusia yang baik (good man) (Al-Attas 1979, 1). Apa maksud dan bagaimana patokan seseorang dikatakan 'baik' itu? Kemungkinan besar jawaban atas pertanyaan ini tidaklah sama, tergantung cara pandang, latar belakang dan kepentingan seseorang yang beragam. Bahkan agama yang mestinya 
memiliki ajaran dan patokan yang sama tentang 'orang baik', dapat dimanipulasi penganutnya sehingga terkesan saling bertentangan.

Bukan hanya itu, agama kadang digunakan untuk tujuan yang bertentangan dengan agama itu sendiri. Radikalisme dan bahkan terorisme misalnya, sering menggunakan baju agama sebagai legitimasinya. Mereka memanfaatkan konsep jihad yang dimanipulasi sesuai dengan kepentingan sendiri.

Dalam proses pendidikan agama Islam, hal yang tidak kalah penting adalah peran guru dan metode pembelajaran. Pendidikan merupakan proses interaksi antara guru (pendidik) dengan peserta didik untuk mencapai tujuan pendidikan yang ditentukan. Peran guru sangat strategis dalam pembelajaran PAI di sekolah maupun perguruan tinggi. Dalam pendidikan agama, guru dan dosen sering menjadi model dan inspiring teaching yang ditiru dan mengilhami peserta didik (Nata 2003, 146).

Guru atau dosen yang moderat dalam pemahaman agamanya akan mendorong peserta didik untuk bersikap moderat pula, sekalipun, misalnya, kurikulum PAI mengajarkan paham dan sikap yang antimultikulturalisme. ${ }^{3}$ Sebaliknya guru atau dosen yang radikal akan mengajarkan ajaran Islam secara harfiyyah dan doktiner, meskipun kurikulumnya relatif toleran dan bersahabat. ${ }^{4}$

Sudah menjadi kenyataan sejarah bahwa pendidikan agama itu rawan terhadap tafsir-tafsir 'jahil' yang mengkorupsi hakekat kebenaran agama untuk kepentingan mazhab dan kelompoknya. Guru dan dosen yang profesional tapi tidak netral saja berpotensi membelokkan ajaran Islam ke arah 'pemahaman agama' yang diinginkan, apalagi guru dan dosen yang

${ }^{3}$ Nilai-nilai anti-multikulturalisme, antara lain adalah: (1) menganggap diri paling benar (truth claim), (2) prasangka dan stereotip (pandangan negatif terhadap pihak lain yang tidak sealiran dengannya), (3) stigma dan penghakiman (bahwa pihak lain sesat), (4) eksklusivisme (anjuran untuk tidak berhubungan dengan pihak lain yang berbeda), (5) arogansi kelompok, (6) pembelaan terhadap aksi kekerasan atas nama agama (baca Baidhawi 2008)

${ }^{4}$ Gagasan perlunya pendidikan multikultural, sebagian besar didasari oleh keharusan melihat keragaman masyarakat, baik suku, agama, budaya dan sebagainya. Menurut J.A., Banks, pendidikan multikultural adalah "an inclusive concept used to describe a wide variety of school practices, programs and materials designed to help children from diverse groups to experience educational quality." (Raihani 2010). 
tidak profesional sekaligus tidak netral. Tidak heran bila di sekolah-sekolah tertentu, para murid dan mahasiswa mungkin diajari untuk mengkafirkan orang yang berbeda agama.

Kenyataan ini dapat terjadi karena guru dan dosen menggunakan pendekatan doktriner dalam pembelajaran agama Islam. Pendekatan ini menanamkan nilai atau ajaran agama dengan jalan menekankan bahwa ajaran agama tidak perlu dipersoalkan tapi cukup diterima apa adanya. Pendekatan doktriner dapat mendorong siswa dan mahasiswa untuk tidak menggunakan nalar dalam memahami agama, harfiyyah, dan mungkin membuat mereka terjebak pada fanatisme dan klaim paling benar sendiri. ${ }^{5}$

Hasil penelitian Fuad Fanani di Jabodetabek menunjukkan bahwa 49 \% siswa setuju dengan aksi radikalisme demi agama (Fanani 2013, 7). Selain itu Nikmah Azekiyah juga merilis bahwa di Yogyakarta terdapat beberapa sekolah menengah atas yang memiliki kecenderungan keras (radikal) dalam memahami keagamaan yang selama ini dianut (Azekiyah 2011); dan lebih khusus paham radikal ini mulai masuk melalui buku teks (Fuad 2015). Banyak siswa yang pemahaman keislamannya menjadi monolitik dan gemar menyalahkan pihak lain. Paham keagamaan yang tertutup ini akan berdampak pula pada pemahaman kebangsaan yang mengalami reduksi dan menipis.

Sejumlah organisasi masyarakat di daerah mengajukan keberatan atas beredarnya buku ajar PAI di sekolah, karena memuat sikap intoleran terhadap perbedaan paham keagamaan dan dalam menyikapi perbedaan mengandung nuansa kekerasan (Pusat Pengkajian Islam dan Masyarakat 2016, 1). Sekolah sangat berpeluang menjadi penyebar paham keagamaan radikal. Proses tranformasi paham radikal perlahan mulai masuk sekolah. Anak-anak sekolah menjadi target khusus rekrutmen kelompok teroris dan radikal. Adanya upaya rekrutmen ke sekolahsekolah, dengan melakukan 'cuci otak' terhadap siswa, yang selanjutnya diisi dengan ideologi radikal tertentu.

Radikalisme dalam pendidikan memiliki potensi ancaman yang berbahaya dalam mewujudkan kelangsungan kualitas pendidikan. Radikalisme bisa muncul kapan saja, dari mana saja dan dapat dilakukan

${ }^{5}$ Secara teoritis, beragam pendekatan yang dapat digunakan dalam mengkaji atau mempelajari Islam, dapat dibaca dalam Abuddin Nata (2001). 
siapa saja. Oleh sebab itu radikalisme perlu disikapi secara utuh dan komprehensif. Bentuk intoleransi pada buku-buku teks tercermin dalam bentuk menyalahkan pendapat atau praktik ibadah yang berbeda. Mempromosikan pendapat yang satu tanpa menghadirkan pendapat lainnya. Memuat pandangan negatif atau stereotip tentang umat lain tanpa menegaskan Islam menghormati kebebasan berkeyakinan dan tanpa menegaskan bahwa antar umat beragama harus rukun dan secara sosial harus bahu membahu sebagaimana Islam ajarkan.

Apabila buku ajar Agama telah dimasuki unsur radikal maka akan sangat berbahaya bagi perkembangan kepribadian dan perilaku siswa. Parisi menjelaskan guru PAI memiliki peranan yang sangat strategis untuk menghambat penyebaran paham radikal di kalangan siswa. Peran guru sangat dibutuhkan. Guru dituntut untuk lebih selektif dalam memilih buku ajar yang akan diberikan siswanya. Guru harus selalu menanamkan pembelajaran tentang toleransi terhadap sesama. Wiyani menjelaskan salah satu upaya guru PAI adalah dengan melakukan praktik deradikalisasi pendidikan Islam melalui pengintegrasian nilai-nilai pendidikan anti terorisme dalam pembelajaran. Pencegahan munculnya paham radikal jauh lebih penting sebelum terjadinya aksi teror. Dengan memberikan pemahaman keagamaan yang benar kepada generasi muda terutama pada para siswa, menjadi satu langkah yang bijaksana agar aksi teror tidak terulang kembali di masa-masa yang akan datang. Misi ajaran Islam yang sebenarnya sangat mulia dan luhur seringkali justru mengalami distorsi akibat pemahaman yang keliru terhadap beberapa aspek ajaran Islam yang berpotensi menimbulkan paham radikalisme.

Pendekatan doktriner dalam pembelajaran PAI dapat menggunakan teknik indoktrinasi dengan beberapa tahap (Thoha 1996, 88). Pertama, tahap brainwashing di mana pendidik mulai menanamkan paham agama baru dengan merusak atau mengacaukan paham agama lama yang sudah mapan sebelumnya. Setelah pikiran siswa kacau dan kosong, daya rasionya tak mampu lagi mengontrol dirinya maka tahap kedua akan dimulai.

Kedua, tahap menanamkan fanatisme (sementara disebut fanatikisasi) di mana pendidik menawarkan dan mengindoktrinasi ide-ide baru yang dianggap benar di saat peserta didik mengalami 
kekacauan pikiran. Apabila peserta didik sudah mulai menerima pahampaham baru secara emosional, setelah itu ditanamkan doktrin yang sesungguhnya. Ketiga, tahap penanaman doktrin (indoktrinasi) dengan menggunakan pendekatan efektif, doktriner dan otoritatif. Ciri khas pendekatan ini adalah hanya dikenal satu nilai kebenaran dan tidak tidak ada alternatif lain. Semua peserta didik harus menerima kebenaran itu tanpa mempertanyakan hakekat kebenaran paham tersebut.

\section{Radikalisasi Buku Keagamaan}

Di dalam proses pendidikan, peran guru/ dosen dan buku yang menjadi pegangan para siswa dan mahasiswa perlu diperhatikan, khususnya menyangkut penyebaran ideologi radikal. ${ }^{6}$ Riset yang pernah penulis lakukan menunjukkan bahwa lembaga-lembaga pendidikan diduga tidak kebal terhadap pengaruh ideologi radikal.

Simpulan di atas didukung oleh fakta bahwa: (1) Beberapa guru PAI mengakui adanya konsep Islam radikal yang mungkin menyebar di kalangan siswa karena kurangnya pengetahuan keagamaan; (2) Unitunit kajian Islam di sekolah-sekolah berkembang baik namun tidak ada jaminan adanya kekebalan dari radikalisme karena proses belajarnya diserahkan kepada pihak ketiga; (3) Di dalam buku rujukan dan kertas kerja terdapat beberapa pernyataan yang dapat mendorong siswa untuk membenci agama atau bangsa lain (Rokhmad 2012).

Proses seseorang menjadi radikal (disebut radikalisasi) disebabkan oleh multifaktor. Salah satu faktor utamanya adalah pertemuan dengan seseorang yang dipandang sebagai guru atau pembimbingnya (murabbi). Setiap guru atau pembimbing memiliki buku pedoman

${ }^{6}$ Radikalisme adalah paham yang menjadi akar dari tindakan radikal. Inilah yang nanti akan membedakan radikalisme yang dipicu oleh masalah politik misalnya, dengan radikalisme yang bersumber dari pemahaman keagamaan yang kurang tepat. Pelaku pembunuhan yang dilambari motif duniawi (ekonomi,sosial, politik, psikologis) misalnya, sejatinya ia telah bertindak dan berpaham radikal karena ia telah menjadikan kekerasan sebagai ideologi untuk menyelesaikan masalah, dan keyakinan itu diwujudkan dalam tindakan membunuh. Tapi ia tidak disebut sebagai pelaku radikalisme, oleh karena konsensus ilmu sosial menyebutkan bahwa ia adalah pelaku pembunuhan (kriminal). Hal ini berbeda dengan pembunuhan yang sekalipun korbannya hanya satu, tetapi jika motifnya karena keagamaan bisa jadi ia dimasukkan dalam pelaku radikalisme. Jadi, radikal adalah konsensus sosial dari ilmuan untuk menyebut tindakan seperti yang diuraikan di atas. 
yang diyakini kebenarannya, kemudian diajarkan, ditransmisikan dan diindoktrinasikan kepada muridnya. Lewat buku inilah, guru dan murid berinteraksi dengan menggunakan buku sebagai sumber dan basis ideologinya. Dan, ciri khas dari teologi maut ini adalah menyebarkan agama secara harfiyyah-doktriner.

Contoh dan analisis yang cukup baik dikemukakan Bassam Tibi tentang peran Sayyid Qutb dalam penyebaran Islam politik (Islamisme) yang berujung pada radikalisme beragama (Tibi 2016). Qutb adalah pentolan organisasi Ikhwan al-Muslimin di Mesir pada 1928 dan menjadi ideolog organisasi tersebut. Qutb yang dieksekusi pada 1966, mungkin tidak membayangkan bahwa visi dan pikiran-pikirannya yang ditulis dalam sebuah buku (ma'alim fi al-thariq) itu menjadi buku wajib yang harus dibaca oleh kelompok Islam radikal atau pengusung negara khilafah Islamiyyah.

Hasan al-Banna adalah pendiri Ikhwanul Muslimin yang pikiranpikirannya termuat dalam Majmu'at Rasa'il al-Imam al-Syahid Hasan al-Banna. Al-Banna adalah seorang praktisi jihadisme yang berpikiran sederhana. Namun, di tangannya jihad klasik diubah menjadi jihadisme. Sedang Qutb adalah pemikir dan bertindak dalam sejumlah besar tulisannya sebagai pemegang otoritas intelektual dalam filosofi Islamisme. Sayyid Qutb, sang rector spiritus Islam, adalah orang pertama yang menafsirkan jihad sebagai 'revolusi dunia Islam' dalam mengupayakan tegaknya tatanan dunia islam. Jihad menjadi 'berkelas' di mata pengikutnya karena ditopang dengan argumentasi politik-agama yang membuai: seolah urusan agama, padahal itu hanyalah politik.

Menurut Bassam Tibi, berbagai pernyataan dan tindakan al-Qaidah bersumber dari Hassan al-Banna dan Sayyid Qutb yang menantang tatanan dunia sekuler, dan Barat itu sendiri. Qutb menandaskan perlunya harb al-afkar (perang pemikiran), yaitu perang global iman (kepercayaan) melawan kufr (ketidakpercayaan/ kekafiran). Perang pemikiran ini adalah jihad global yang tidak tergantung pada taktik teroris. Perang melawan kekafiran ini memanfaatkan medan pertempuran yang sangat luas, termasuk buku dan internet. Bila seksama mengkaji, ada kesengajaan yang sistematis untuk memasukkan ajaran Qutb dalam buku pelajaran PAI dan bacaan keagamaan lain agar dibaca oleh para 
siswa. Pelakunya adalah para penulis dan guru PAI yang — entah sadar atau tidak-menjadi penyambung lidah ajaran Qutb tanpa memahami dampak dan konsekuensinya bagi kehidupan keagamaan dan kebangsaan bangsa Indonesia.

Dalam Ma'alim fi al-Thariq, sebagaimana dikutip dari Bassam Tibi, Sayyid Qutb menyerukan tatanan ilahi hakimiyyat Allah (pemerintahan Allah) ke seluruh dar al-Islam. Tatanan ilahi ini akan menciptakan revolusi Islam yang dirancang untuk mengarahkan ke perdamaian dunia di bawah syarat-syarat siyadat al-Islam (supremasi Islam) atas seluruh dunia. Menurut Qutb, inilah faridhah (kewajiban) agama untuk mengejar jihad sebagai 'revolusi dunia Islam' dalam rangka memberantas jahiliyyah (yang identik dengan kekafiran).

Ketokohan dan pengaruh Qutb tak terbantahkan. Pengaruh ini tidak terbatas pada kelompok-kelompok jihadis seperti al-Qaidah, tetapi juga meluas ke organisasi Islamis institusional seperti AKP (Partai Keadilan dan Pembangunan/ Adalet ve Kalkinma Partisi pimpinan Ahmet Davotoglu. Secara de facto, Recep Tayyib Erdogan yang berkuasa) di Turki. Menurut jurnalis Republika, Ikhwanul Kiram Mashuri, AKP sebenarnya termasuk partai Islam moderat. Namun memperhatikan langkah-langkah politik Erdogan ketika menghalau musuh bebuyutannya, Abdullah Gullen dan simpatisannya, pasca percobaan kudeta, tampaklah kecenderungan politik Islam yang dibawa.

Dalam konteks Indonesia, ajaran Qutb juga mengakar di kalangan gerakan tarbiyah, Partai Keadilan Sejahtera (Rokhmad 2014) dan Hizbut Tahrir Indonesia. Ajaran Qutb disimpan dan disebarluaskan lewat buku dan internet sehingga mudah dibaca diwariskan pada generasi berikutnya.

Kompleksitas penyebaran radikalisme perlu penangan segera khususnya pada siswa di lembaga pendidikan. Institusi pendidikan yang perlu didorong terlibat lebih aktif dalam membendung arus radikalisasi. Institusi pendidikan terutama yang mengakar secara kuat di kalangan umat Islam dapat mengembangkan peran kultural dalam proses deradikalisasi. Penanggulangan radikalisme di lembaga pendidikan ini dapat ditanggulangi melalui beberapa alternatif berikut: Pertama, Mengedepankan dialog dalam pembelajaran agama Islam. Pembelajaran 
Agama Islam yang mengedepankan indoktrinasi faham tertentu dengan mengesampingkan faham yang lain hanya akan membuat para siswa memiliki sikap eksklusif yang pada gilirannya kurang menghargai keberadaan orang atau kelompok lain. Sudah saatnya para guru PAI membekali dirinya dengan pemahaman yang luas dan lintas madzhab sehingga mampu mememenuhi kehausan spiritual siswa dan mahasiswa dengan pencerahan yang bersendikan kedamaian dan kesejukan ajaran Islam

Kedua, Pemantauan terhadap kegiatan dan materi mentoring keagamaan. Keberadaan kegiatan mentoring agama Islam atau kegiatan Rohis yang lain di sekolah sesungguhnya sangat membantu tercapainya tujuan pendidikan agama Islam. Namun jika guru PAI tidak melakukan pendampingan dan monitoring, dikhawatirkan terjadi pembelokan kegiatan mentoring dan Rohis lainnya. Bagi pengurus Rohis, sudah seharusnya mereka selalu berkonsultasi dengan pihak guru Agama atau pihak-pihak lain yang dipandang memiliki wawasan keislaman moderat agar tidak terbawa arus pada pemahaman Islam yang sarat dengan muatan radikalisme.

Ketiga, Pengenalan dan penerapan pendidikan multikultural. Pendidikan multikultural pada dasarnya adalah konsep dan praktek pendidikan yang mengedepankan nilai-nilai persamaan tanpa melihat perbedaan latar belakang budaya, sosial-ekonomi, etnis, agama, gender, dan lain-lain. Semua orang memiliki kesempatan yang sama untuk memperoleh hak pendidikan. Dengan penerapan pendidikan multikultural, diharapkan semangat eksklusif dan merasa benar sendiri sebagai penyebab terjadinya konflik bisa dihindari. Seorang multukulturalis sejati adalah pribadi yang selalu bersikap toleran, menghargai keberadaan liyan tanpa dia sendiri kehilangan identitasnya. Kalau tujuan akhir pendidikan adalah perubahan perilaku dan sikap serta kualitas seseorang, maka pengajaran harus berlangsung sedemikian rupa sehingga tidak sekedar memberi informasi atau pengetahuan melainkan harus menyentuh hati, sehingga akan mendorongnya dapat mengambil keputusan untuk berubah. Pendidikan agama Islam, dengan demikian, di samping bertujuan untuk memperteguh keyakinan pada agamanya, juga harus diorientasikan untuk menanamkan empati, simpati dan solidaritas 
terhadap sesama. Dengan demikian, dalam hal ini, semua materi bukubuku yang diajarkannya tentunya harus menyentuh tentang isu pluralitas. Dari sinilah kemudian kita akan mengerti urgensinya untuk menyusun bentuk kurikulum pendidikan agama berbasis pluralisme agama.

\section{Kesimpulan}

Buku merupakan instrumen penting dalam pendidikan. Dalam pendidikan Agama Islam, buku menempati posisi yang jauh lebih krusial dibandingkan dengan pendidikan lainnya. Ibarat rasul, sebuah buku bertugas menerima, menyimpan dan menyebarluaskan doktrin-doktrin agama. Di dalam setiap buku, bersemayam ideologi dan kepentingan para penulisnya.

Pada era internet, buku tidak kehilangan vitalitas dan pengaruhnya bagi pembaca. Dengan segala kelebihan dan kekurangannya, buku tetap dicari oleh pembaca. Oleh karena peran dan fungsinya yang sangat penting, buku telah menjadi medan harb al-fikr (perang pemikiran) yang sangat strategis bagi semua pihak. Penulis yang bijak akan menjadikan buku sebagai sumber inspirasi untuk menanam kebaikan dan kedamaian. Bagi penulis yang memiliki kepentingan tertentu, buku adalah media paling baik untuk mengajak dan mempengaruhi pembaca untuk meyakini doktrin yang disampaikan dalam buku tersebut, meski dengan cara memanipulasi agama untuk kepentingan politik tertentu.

Oleh karena itu, buku bisa jadi memiliki wajah ganda. Ibarat berlian di satu sisi, dan 'kotoran' di sisi lainnya. Ia dipuja karena memuat ilmu pengetahuan tapi juga sering dicaci karena mengajarkan paham radikal. Tentu saja, buku adalah teks mati. Ia akan hidup kalau dibaca oleh para pembaca. Sejelek apapun isi sebuah buku, sangat tergantung pembacanya. Di tangan orang baik, buku apapun isinya, adalah jendela ilmu pengetahuan. 


\section{DAFTAR PUSTAKA}

Al-Attas, Syed Muhammad Al-Naquib, ed. 1979. Aims and Objectives of Islamic Education. Jeddah: King Abdul Aziz University.

Azekiyah, Nikmah. 2011. Hairus Salim Dan Najib Kailani, Politik Ruang Publik Sekolah. Yogyakarta: LKiS.

Baez, Fernando. 2013. Penghancuran Buku: Dari Masa Ke Masa. Jakarta: Marjin Kiri.

Baidhawi, Zakiyudin. 2008. Pendidikan Agama Berwawasan Multikulturalisme. Jakarta: Gelora Aksara Pratama.

Balitbang Semarang. 2017. Evaluasi Isi Buku Bacaan Keagamaan Rohis SMU. Semarang: Balai Penelitian dan Pengembangan Agama.

Eatwell, Roger, and Anthony Wright, eds. 2001. Ideologi Politik Kontemporer. Yogyakarta: Jendela.

Endarmoko, Eko. 2006. Tesaurus Bahasa Indonesia. Jakarta: Gramedia.

Fadjar, Abdullah. 2007. Laporan Penelitian Islam Kampus. Jakarta: Ditjen Diktis Depdiknas.

Fanani, Ahmad Fuad. 2013. "Fenomena Radikalisme Di Kalangan Kaum Muda." Maarif: Arus Pemikiran Islam dan Sosial 8(1).

Fuad, A. Jauhar. 2015. Penetrasi Neo-Salafisme Dalam Lembar Kerja Siswa Di Madrasah. Jakarta: Kementerian Agama.

Krathwohl, David R. 1964. Taxonomy of Educational Objectives: Handbook II Affective Domain. New York: David McKay.

Laksono, Kisyani. 2016. Manual Pendukung Gerakan Literasi Sekolah. Jakarta: Kemendikbud.

Nata, Abuddin. 2001. Metodologi Studi Islam. Jakarta: Raja Grafindo Persada.

_-_. 2003. Manajemen Pendidikan: Mengatasi Kelemahan Pendidikan Islam Di Indonesia. Jakarta: Kencana.

Nottingham, Elizabeth K. 1997. Agama Dan Masyarakat: Suatu Pengantar Sosiologi Agama. Jakarta: Rajawali Press. 
O’Dea, Thomas F. 1996. Sosiologi Agama: Suatu Pengenalan Awal. Jakarta: Rajawali Press.

Pedersen, Johannes. 1996. Fajar Intelektualisme Islam: Buku Dan Sejarah Penyebaran Informasi Di Dunia Arab. ed. Alwiyah Abdurrahman. Bandung: Mizan.

Pendis. 2007. Standar Isi Dan Standar Kelulusan Pendidikan Agama Islam. Jakarta: Departemen Agama.

Pusat Pengkajian Islam dan Masyarakat. 2016. Tanggung Jawab Negara Terhadap Pendidikan Agama Islam. Jakarta: UIN Syarif Hidayatullah.

Qaththan, Manna' Khalil. 1988. Mabahits Fi Ulum Al-Qur'an. Mekah: Maktabah AL-Ma'arif.

Raihani. 2010. “Islam Dan Kemajemukan Indonesia.” In Kumpulan Makalah ACIS, Banjarmasin: AICIS.

Rokhmad, Abu. 2010. Hermeneutika Tafsir Al-Ibriz. Semarang: Rasail.

-_—. 2011. Radikalisme Islam Dan Upaya Deradikalisasi Paham Radikal Dalam Pembelajaran PAI Pada SMU Di Kota Semarang. Semarang: LP2M Universitas Islam Negeri Walisongo.

___ . 2012. "Radikalisme Islam Dan Upaya Deradikalisasi Paham Radikal." Walisongo: Jurnal Penelitian Sosial Keagamaan 20(1).

___. 2014. “Dasar Negara Dan Taqiyyah Politik PKS.” Walisongo: Jurnal Penelitian Sosial Keagamaan 22(1).

Romdhoni, Ali. 2013. Al-Qur'an Dan Literasi. Jakarta: Linus.

Rosda, Tim Penulis. 1995. Kamus Filsafat. Bandung: Rosdakarya.

Thoha, M. Chabib. 1996. Pendidikan Islam. Yogyakarta: Pustaka Pelajar. Tibi, Bassam. 2016. Islam Dan Islamisme. Bandung: Mizan.

Toer, Pramoedya Ananta. 2005. Bumi Manusia. Jakarta: Lentera Dipantara. 
This page intentionally left blank 